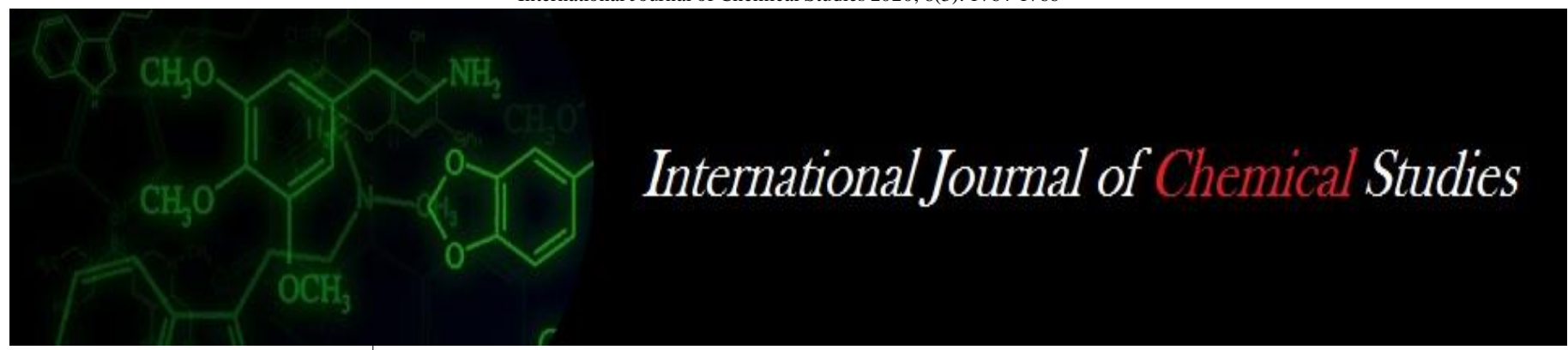

P-ISSN: 2349-8528

E-ISSN: 2321-4902

www.chemijournal.com

IJCS 2020; 8(3): 1764-1766

(C) 2020 IJCS

Received: 18-03-2020

Accepted: 20-04-2020

K Venkatalakshmi

Assistant Professor (Agronomy)

Krishi Vigyan Kendra,

Vridhachalam, Cuddalore

district, Tamil Nadu, India
Corresponding Author: K Venkatalakshmi

Assistant Professor (Agronomy)

Krishi Vigyan Kendra,

Vridhachalam, Cuddalore

district, Tamil Nadu, India

\section{Demonstration of Pani Pipe - indicator tool of alternate wetting and drying in low land transplanted paddy}

\section{K Venkatalakshmi}

DOI: https://doi.org/10.22271/chemi.2020.v8.i3x.9453

\begin{abstract}
In Cuddalore district, an area of 1.25 lakh hectare is cultivated under paddy with the production of 6.7 metric tonnes with the productivity of 7.4 tonnes/ha. Water plays a prominent role in rice production. Paddy is one of higher water consuming crop. Major portion of i.e. 80 per cent of total irrigation water is utilized by the irrigated transplanted paddy which has to be judiciously utilized. Keeping the above view the present study was conducted by KVK, Cuddalore as Front-line Demonstration during the year of 2016-17.

The results of the demonstration showed that yield obtained by Alternate Wetting and Drying (AWD) through Pani Pipe recorded higher number of tillers $/ \mathrm{m}^{2}$ (10.4 per cent), higher yield $(6050 \mathrm{~kg} / \mathrm{ha}$ ) than the farmers practice of flood irrigation $(5420 \mathrm{~kg} / \mathrm{ha})$. Number of irrigations by AWD through Pani Pipe were 32 per cent lower than the farmer's practice of flood irrigation.
\end{abstract}

Keywords: Front line demonstration, alternate wetting and drying, pani pipe, paddy, flood irrigation

\section{Introduction}

Rice is one of the major food grain crop for India. More than $80 \%$ of the fresh water resources in Asia are used for agriculture, of which about half of the total irrigation water is used for rice production (Dawe et al., 2003) ${ }^{[2]}$. Estimate by IRRI, Philippines, 2009 says that being one of the least water use efficient crop, rice needs about 5000 liters of water for producing $1 \mathrm{~kg}$ of un-milled rice. The traditional water management viz. continuous flooding system makes the production of rice as a less efficient in water use Considerable quantity of water savings with higher paddy yields by following Alternate wetting and drying method of irrigation leads to average $35 \%$ reduction in irrigation water consumption per hectare (Jagannath et al., 2013) ${ }^{[4]}$. In Cuddalore district, more than 1.25 lakh hectares of land is under paddy cultivation during Samba season. Major problem identified were indiscriminately use of irrigation water to the paddy crop by flooding and farmers were lack of awareness about Alternate Wetting and Drying through Pani Pipe. By considering the above present demonstration was carried out to create awareness to the paddy farmers of Cuddalore district about judicious use of irrigation water by using Pani Pipe at the same time without any yield penalty.

\section{Methodology}

During 2015-16 On Farm Trial (OFT) was conducted in 10 locations of Cuddalore district. Based on the performance, up scaling of technology was carried as front-line demonstration (FLD) during the year of 2016-17 in 6 locations of Cuddalore. The FLD was conducted in various location of Vridhachalam block. The crop was raised in Samba season (SeptemberOctober) as transplanted crop with the Paddy var. BPT 5204.

Pani Pipe is a $30 \mathrm{~cm}$ long plastic of $15 \mathrm{~cm}$ diameter with drilled holes, which is buried into the rice field near to the bund to a $15 \mathrm{~cm}$ depth. Half the pipe protrudes above the soil surface. Pani Pipe was installed 20 days after transplanting. When the water level inside the Pani Pipe drops to $15 \mathrm{~cm}$ below ground level, the field is ready to be irrigated. One week before or after flowering the field is kept continuously flooded with water to a depth of $5 \mathrm{~cm}$. The Pani Pipe appearance in the field is shown as in Fig 1. This threshold of $15 \mathrm{~cm}$ is called 'safe AWD' as it does not have any negative impact on yield. Demonstrated technology of alternate and wetting 
in transplanted low land paddy compared is with farmer's practice of flooding. The following technologies were demonstrated in FLD by KVK, Vridhachalam during 2016-17 in 6 locations of farmer's field.

- The following technologies were demonstrated in paddy crop to the selected farmers field

- Seed treatment with Pseudomonas fluorescens @ $10 \mathrm{~g} / \mathrm{kg}$ of seeds
- Seed treatment with bio fertilizer Azospirillium and Phosphobacteria@400 g/acre

- Application of $\mathrm{ZnSO}_{4}$ to the paddy crop @ $10 \mathrm{~kg} / \mathrm{acre}$ as enriched farm yard manure

- Irrigation applied through Alternate wetting and drying method through Pani Pipe to the paddy crop
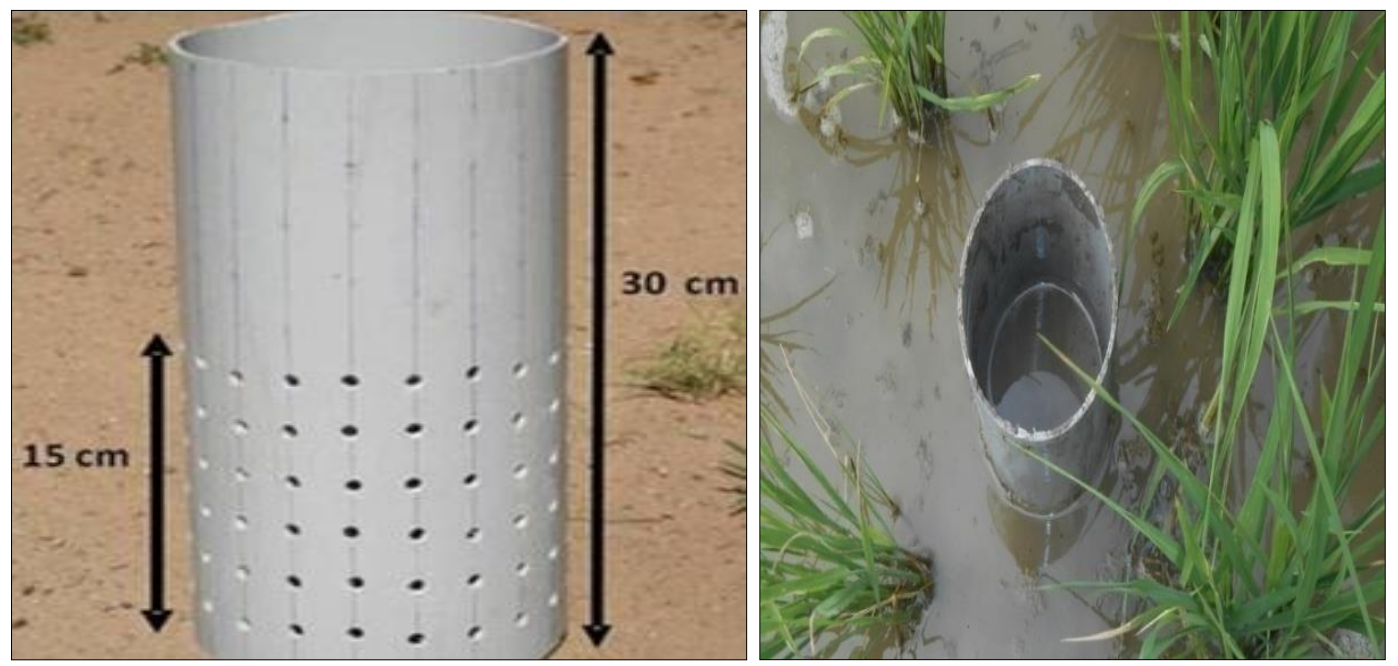

Fig 1: General view of the Pani Pipe in the field

\section{Results and discussions}

More number of tillers $/ \mathrm{m} 2$ (284.7) were recorded higher in the AWD through Pani Pipe than the farmer's practice of flood irrigation (262.4). More number of panicles /plant (13.3) was recorded higher in the AWD through Pani Pipe than the farmer's practice (10.3) of flood irrigation. This was similarly reported by Santheepan and Ramanathan, $2016^{[5]}$. Yield recorded at irrigation by AWD through Pani Pipe (6050 $\mathrm{kg} / \mathrm{ha}$ ) is higher than the farmers practice of flood irrigation $(5420 \mathrm{~kg} / \mathrm{ha})$. This is 10.4 per cent higher than the farmers practice. Because AWD improves the aeration in the root zone, their by more number of tillers $/ \mathrm{m}^{2}$ has been produced (Table 1).1000 seed weight is $14.8 \mathrm{~g}$ in demonstration plot and $14.3 \mathrm{~g}$ in farmers practice of flood irrigation (Daniela $e t$ al., 2017)

No. of irrigations by AWD through Pani Pipe (17 nos.) were lower than the farmer's practice of flood irrigation (25 nos.). From one hectare of land nearly 36 lakh litres of water is saved. Marked wooden sticks are used to measure the irrigation water level in the field which is placed at different locations in the field.

The net profit realized is higher in the AWD through Pani Pipe (Rs.70,375/ha) than the farmers practice of flood irrigation (Rs. 52,480/ha). The benefit cost ratio also recorded higher (2.1) in AWD through Pani Pipe in low land transplanted paddy crop than the farmers practice of flood irrigation (1.8) (Fig 2 and Table 1).

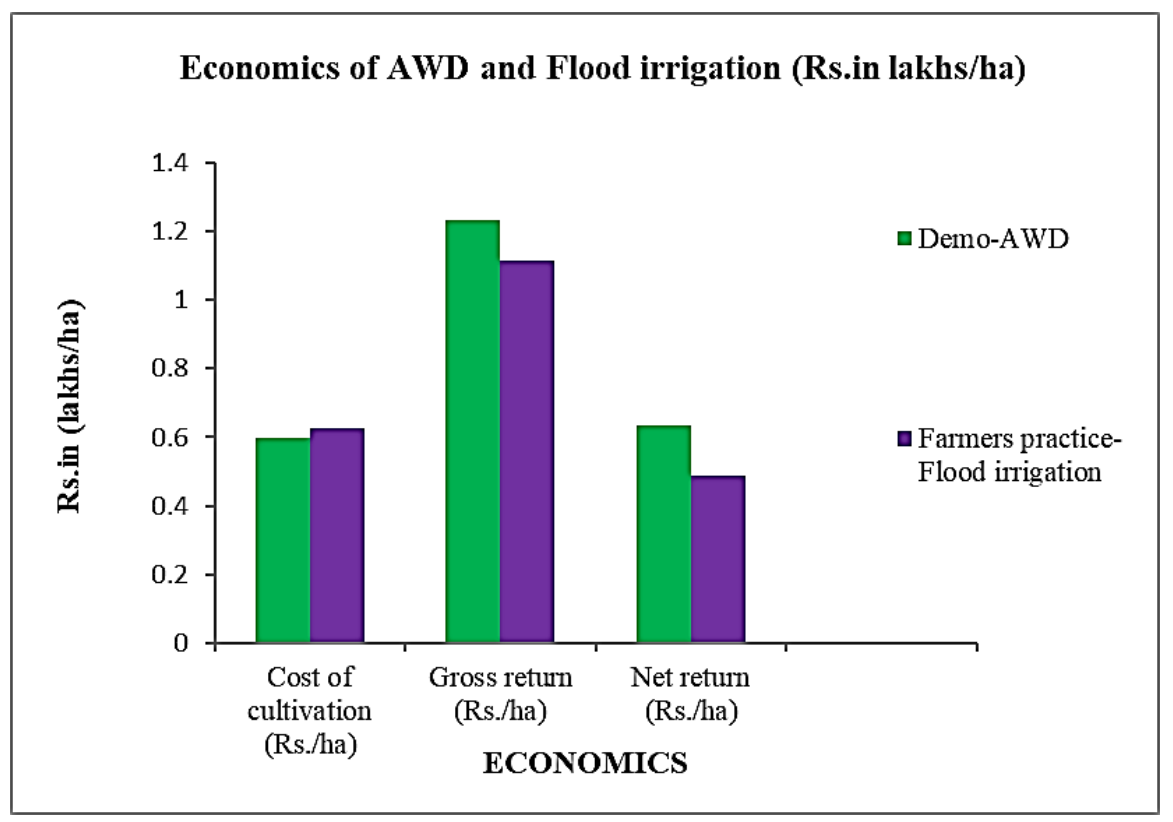

Fig 2: Economics of paddy in AWD irrigation practices Vs. Farmers practice of Flood irrigation 
Table 1: Comparison of yield attributes, yield and B:C ratio in paddy by AWD irrigation through Pani Pipe compared with farmer's practice of flood irrigation.

\begin{tabular}{|c|c|c|c|}
\hline S. No. & Parameters & AWD through Pani Pipe (Demonstration) & Farmers practice of flood irrigation (Check) \\
\hline 1. & Number of tillers /m2 & 284.7 & 262.4 \\
\hline 2. & Number of panicles /plant & 13.3 & 10.3 \\
\hline 3. & 1000 grain weight $(\mathrm{g})$ & 14.8 & 14.3 \\
\hline 3. & Yield (kg/ha) & 5730 & 5177 \\
\hline 4. & No. of irrigations given & 17.7 & 24.3 \\
\hline 6. & B:C ratio & 2.1 & 1.8 \\
\hline
\end{tabular}

*Data is not statistically analysed.

Farmers feedback and horizontal spread

- Less number of irrigations was given. Hence water is saved by AWD through Pani Pipe technology

- Cost of cultivation was reduced by less diesel consumption.

- More number of tillers were produced which leads to higher yield

- Less pest and disease incidence were occurred due to AWD practice.

- Pani Pipe will be easily manufactured by farmers themselves, simple method to follow.

Horizontal spread: Considerable number of farmers in and around the locality, started adopting this technology because of the very sincere training efforts taken by the KVK, Vridhachalam. Pani Pipes were installed 61,140 acres of paddy field in non delta regions of Cuddalore district through TANI scheme by the Department of Agriculture with the technical support of KVK, Vridhachalam.

Conclusion: We found that the AWD threshold had a major effect on yields and that yields could be maintained in most soils under mild AWD. Using AWD also provided a 37 per cent reduction in number of irrigations given. Finally, these outcomes demonstrate that AWD is a promising management practice with respect to judicious application of irrigation water, besides increases the paddy yield to the tune of 10.4 per cent.

\section{References}

1. Daniela R Carrijo, Mark E Lundy, Bruce A Linquist. Rice yields and water use under alternate wetting and drying irrigation: A meta-analysis. Field crop research. 2017; 203(1):173-180.

2. Dawe D, Dobermann A, Ladha JK, Yadav RL, Lin B, Lal $\mathrm{P}$ et al. Does organic matter improve the sustainability and profitability of intensive rice systems. - Field Crops Res. 2003; 83:191-213.

3. IRRI. Rice fact sheet: Saving water: Alternate Wetting Drying (AWD), International Rice Research Institute, Las banos, 2009.

4. Jagnnath P, Pullabhotla H, Uphoff N. Meta analysist evaluating water use: water saving and water productivity in irrigated production of rice with SRI Vs. standard management methods. Taiwan Water conservation. 2013; 61:14-49.

5. Santheepan S, Ramanathan SP. Investigation on AWDI method with field water tube for rice production under SRI. International Journal of Agricultural Science and Research. 2016; 6(3):117-124. 